\title{
How Feminist is the Belarusian Revolution? Female Agency and Participation in the 2020 Post-Election Protests
}

\author{
Natallia Paulovich
}

The scale of protests in Belarus after the August 2020 presidential elections has been unprecedented. As I write this article at the end of 2020, the Belarusian protests are still underway. The protests began as a reaction to the falsified election results. They picked up steam following state-sponsored acts of torture against the people who had been detained during the first post-election demonstrations. Forms of protest have changed over time; women's marches, for example, started on August 14, just four days after the falsified elections. At this point Belarusian women formed so-called "Solidarity Chains" along the streets of Minsk as a reaction to police brutality and acts of torture in prisons targeted at men. Mothers, wives, daughters, and sisters poured out into the streets, expressing their pain and anger in the face of the unfolding events. This put Belarusian women at the forefront of the protests. Their participation later developed into more organized actions, such as a weekly Saturday Women's March. Such activity is unprecedented and has become grounds for the international mass media calling the current protests "the revolution with a female face."1

The active participation of women in pushing for political change, however, could be observed even before the August protests began. Three women led the change. One was Sviatlana Tsikhanouskaya, the wife of a popular Belarusian blogger who was imprisoned before he could register his candidacy; another was Veranika Tsapkala, the wife of a potential candidate who left Belarus to avoid arrest. The third in the "triumvirate" was Maryia Kalesnikava, campaign manager for Viktar Babaryka, a jailed banker who had also hoped to beat Aliaksandar Lukashenka. Together, they formed a coalition to support Tsikhanouskaya's presidential campaign. This suggests that the active participation of women before and after the elections did not

1. Anna Shadrina, "Tsvety protesta: Kak zhenshchiny stali novoǐ politicheskoǐ siloǐ Belarusi,” Forbes, March 9, 2020, 2020, at https://www.forbes.ru/forbes-woman/408215cvety-protesta-kak-zhenshchiny-stali-novoy-politicheskoy-siloy-belarusi?fbclid=I wAR2m8fjxXw86_7atbsnb9rTrEKiOj4fyOOdzjtQK34qnbZRyZQb_Kcc6Z9c (accessed February 4, 2021); Ivan Nechepurenko, "In Belarus, Women Led the Protests and Shattered Stereotypes,” The New York Times, October 11, 2020, at https://www.nytimes. com/2020/10/11/world/europe/in-belarus-women-led-the-protests-and-shatteredstereotypes.html (accessed February 4, 2021); Yasmeen Serhan, "When Women Lead Protest Movements: The Demonstrations in Belarus Point to a Broader Trend,” The Atlantic, September 12, 2020, at https://www.theatlantic.com/international/archive/2020/09/ belarus-protests-women/616288/ (accessed February 4, 2021).

Slavic Review 80, no. 1 (Spring 2021)

(C) The Author(s), 2021. Published by Cambridge University Press on behalf of the Association for Slavic, East European, and Eurasian Studies. This is an Open Access article, distributed under the terms of the Creative Commons Attribution licence (http:// creativecommons.org/licenses/by/4.0/), which permits unrestricted re-use, distribution, and reproduction in any medium, provided the original work is properly cited.

doi: 10.1017/slr.2021.22 
start as a feminist project but rather as a spontaneous reaction to mass-scale arrests of male political actors. ${ }^{2}$

One of the main tactics of female protesters after the elections was dressing in white and attempting to shield male ptotesters with flowers. The usage of traditional feminine imagery and feminine aesthetics also raises the question about the validity of the claim that the Belarusian protests are a feminist project. I argue that the current mobilization of Belarusian women might be analyzed as an agentic act, however, where agency is not simply a synonym for resistance to relations based on domination, but the capacity for action enabled by specific relations based on subordination. ${ }^{3}$ In this article, I will examine acts of agency and attempt to see what they reveal about the female participants of the protests who are aware of their resources and power. The analysis is based on media discourse, visual materials, and social-media discussions among the participants and external observers of the Belarusian post-election protests.

\section{Agency or Heteropatriarchal Values}

Anthropologist Saba Mahmood, in her research on women's participation in the Islamic piety movement in Cairo in the 1970s, claimed that "liberal assumptions about what constitutes human nature and agency become integral to our humanist intellectual traditions." 4 These assumptions are based on the belief that human agency consists of acts that challenge social norms, but practices such as women's active support for the piety socioreligious movement in Egypt that maintain principles of female subordination, cannot be perceived as agentic. ${ }^{5}$ Mahmood's main contribution was calling attention to "different modalities of agency involved in acting, transgressing, or inhabiting ethical norms and moral principles," even if they take place within a system of inequality. ${ }^{6}$ In her opinion, this understanding of agency as a modality of action allows for the broadening of debates about gender in non-western societies beyond the analysis of the patriarchy. Moreover, it enables a conversation about the richness of female active agents, especially in regard to their embodied experience. ${ }^{7}$

The application of Mahmood's approach to the east European context was subsequently undertaken by Alexei Yurchak in his ethnographic study

2. Important insights into the nature of women's agency before the elections in 2020 have been made by the sociologist Elena Gapova in her text "Svetlana Tikhanovskaia: Ot lichnogo k politicheskomu," Open Democracy, August 6, 2020, at https://www. opendemocracy.net/ru/tikhanovskaya-ot-politcheskogo-lichnomy/ (accessed February 4, 2021).

3. Saba Mahmood, Politics of Piety: The Islamic Revival and the Feminist Subject (Princeton, 2012), Kindle Edition, loc. 773.

4. Mahmood, Politics of Piety, loc. 534.

5. Ibid., loc. 530, 538.

6. Ibid., loc. 5485-86.

7. Ibid., loc. 547, 552, 566. See also interpretation of Mahmood's approach towards female involvement in feasting culture in Georgia: Natallia Paulovich, "A Breadwinner or a Housewife? Agency in the Everyday Image of the Georgian Woman," Anthropology of the Contemporary Middle East and Central Eurasia. 3, no. 2 (September 2016): 24-44. 
of late socialism, when individuals were able to exercise their agency despite the repressive environment in which they lived. ${ }^{8}$ Later, in 2017, in their introductory article to The Journal of Soviet and Post-Soviet Politics and Society, editors Felix Ackermann, Mark Berman, and Olga Sasunkevich applied Yurchak's ideas by attempting to search for agency in Belarusian society, which had previously been analyzed through the lens of victimhood. ${ }^{9}$ They stated that the permanent focus on state actions represented by Lukashenka and his "one-man-show character" could lead to a research perspective that pays little heed to the actions of ordinary people. According to them, the best way to avoid this bias is to look at "the subject's inner world, weave into their analysis examples of first-person testimony and other forms of public selfexpression." 10 The effect of this careful attention to people's lives may reveal a broad range of hidden subjectivities.

This perspective could be applied to the interpretation of women's participation in the recent protests in Belarus, where female voices and actions serve as testimonies of their agency functioning within structures of subordination. These structures often support hegemonic discourses, including the most prevalent one that enacts heteropatriarchal values. In the opinion of Belarusian feminist and protester Irina Solomatina, Head of Council for the Belarusian Organization of Working Women, these values in Belarusian society are too persvasive to ignore. She is skeptical about whether Belarusian female protesters can successfully subvert these discourses, and thus doubtful about calling the current events a "feminist project." 11

Furthermore, Solomatina stresses that it is exactly the women of the Belarusian opposition that reinforce these heteropatriarchal values. She reminds us that this trend was started by Tsikhanouskaya herself during the presidential campaign, through emphasizing her maternal experience and love for her husband. ${ }^{12}$ In fact, she was criticized for using gender essentialist tropes when she declared that instead of running in the election, she would rather return home and cook for her family. Local feminists immediately accused her of promoting a family structure with a dominant father, a subordinate wife, and their children, thus (re)enacting heteropatriarchal

8. Alexei Yurchak, Everything Was Forever, Until It Was No More: The Last Soviet Generation (Princeton, 2005).

9. Felix Ackermann, Mark Berman, and Olga Sasunkevich, "In Search of Agency: Examining Belarusian Society from Below," Journal of Soviet and Post-Soviet Politics and Society 3, no. 1 (2017): 1-20; See also about the victimhood project of Belarusians in Nelly Bekus, "Agency of Internal Transnationalism in Social Memory," British Journal of Sociology 70, no. 4 (2019): 1602-23.

10. Ackermann, Berman, and Sasunkevich, "In Search of Agency," 4.

11. Nina Potarskaia interview with Irina Solomatina, "U protesta ne zhenskoe litso. Interv'iu s Irinoǐ Solomatinoǐ o belorusskikh protestakh,” Commons, October 6, 2020, at https://commons.com.ua/ru/u-protesta-ne-zhenskoe-lico-intervyus-irinoj-solomatinoj-o-belorusskih-protestah/?fbclid=IwAR1q1SWZt5cwDP_ DPJuAgNJx3p0KHJpcDTS7f7Kn1JA05LtchHgOwFzCA80 (accessed February 4, 2021).

12. Luba Fein interview with Irina Solomatina, "Women and Feminism in Belarus: The Truth behind the 'Flower Power,"' FiLiA, September 21, 2020, at https://filia.org.uk/ news/2020/9/21/women-and-feminism-in-belarus-the-truth-behind-the-flower-power?f bclid=IwAR1X14Qgi69JlinIagEBKzPyByZi-X51dnucT20V-xRNidayYci7Irv4Ixw (accessed February 4, 2021). 
values in which the woman devotes her life to the man. ${ }^{13}$ Furthermore, the joint representatives of the opposition, Sviatlana Tsikhanouskaya, Veranika Tsapkala, and Maryia Kalesnikava, who became active in place of the intended male presidential candidates, were fighting for "their men." In the public discourse, they immediately started to be called the "the three graces" and "our girls." They became the targets of misogynistic reactions on social media. One comment read as follows: "The regime sucks so bad that even a housewife could become president." 14

Such an interpretation is reinforced by visual images of women protesting in white clothes with flowers, singing lullabies, sometimes even barefoot, embracing the representatives of the special military forces and giving them flowers. As a result, innocence, whiteness, and even childishness became the main symbols of the protests. Solomatina and her co-author, the researcher Vica Schmidt, do not see power in these images. In their opinion, such acts merely constitute self-sacrifice in the name of heteropatriarchal values and, as such, are a betrayal of the feminist agenda. ${ }^{15}$

In feminist literature, however, the issue of (re)enacting heteropatriarchal values by women who are active in socio-political life is closely connected to the organization of political space, citizenship, and agency, which tend to be "polarized along gender lines."16 For instance, research done by Suvi Salmenniemi into civic organizations in Russia at the beginning of 2000 shows that in the post-Soviet context, civic activity is often associated with femininity, "where women bear the social costs of transformation," but this does not mean that such activity is deprived of agency. ${ }^{17}$ Therefore, there is a need to carefully analyze women's practices and the ways in which they subvert dominant associations. Such research can help find the answer to how these practices could be redeployed not only for the interest of researchers, but also the personal benefit of the women who apply them. ${ }^{18}$

\section{Dominant Discourses and Their Subversion}

For individuals, civic activity is a form of practicing citizenship and negotiating one's relationships to the state. ${ }^{19}$ As was previously mentioned, this practice is constructed as gendered, and various discourses support this interconnection. The most prevalent form for women is the discourse of female moral agency, through which qualities such as self-sacrifice and altruism are

13. Anne McClintock, Aamir Mufti, and Ella Shohat eds., Dangerous Liaisons: Gender, Nation, and Postcolonial Perspectives (Minneapolis, 1997).

14. Fein, Women and Feminism in Belarus.

15. "Beloruskiǐ 'chernyǐ iashchik': Proizvol vlasti kak (ne)sostoiavshiǔsia politicheskiǐ tranzit?” October 3, 2020, at https://syg.ma/@sygma/bielaruskii-chiernyiiashchik-proizvol-vlasti-kak-nie-sostoiavshiisia-politichieskii-tranzit?fbclid=IwAR2 $\mathrm{m} 8$ fjxXw86_7atbsnb9rTrEKiOj4fyOOdzjtQK34qnbZRyZQb_Kcc6Z9c (accessed February 4, 2021).

16. Suvi Salmenniemi, "Civic Activity-Feminine Activity? Gender, Civil Society and Citizenship in Post-Soviet Russia,” Sociology 39, no. 4 (October 2005): 735.

17. Ibid., 735, 748.

18. Mahmood, Politics of Piety, loc. 544.

19. Salmenniemi, “Civic Activity-Feminine Activity?” 737-38. 
perceived as essential in achieving the "common good," and that "woman's wisdom" could support this. ${ }^{20}$

The Belarusian case shows that self-sacrifice, along with a perceived moral high ground, appears as one of the main drivers for women's participation in the protests. Fatima Kamara, a mother of five, claimed that her main motivation for taking part in the peaceful marches was a deep disagreement with the Belarusian government. ${ }^{21}$ In Fatima's interview given with tut.by, an independent media outlet, the prevalent narrative is the woman's responsibility to protect her children for whom the current regime poses a significant threat, failing to provide any certainty about their future. Moreover, in August-October 2020, the emphasis on the so-called "protection of children" accrued special meaning when the current government tried to manipulate protesters by threatening to take away the children of parents who take to the streets. In this context, Fatima stresses, "Some services may try to put pressure on me through the children. If something like this happens, I will fight."22

Generally speaking, the Autumn 2020 protests saw a similar perception of the protection of children as a mother's duty. First of all, this could be seen on numerous posters which women took to the streets: "Don't be sorry-beat me! Be sorry for your son" (an allusion to Lukashenka's son); "Using children as blackmail is mean"; "I'm a mother and not a target for OMON [the riot police]"; "I'm against violence. I'm here for the kids"; and "Mothers won't forgive the torture and deaths of children." This shows that women perceived their protests as entirely justified because it had been the result of their emotional reactions to, among other things, the beatings and acts of torture against people they know. And this is what gave them strength. ${ }^{23}$

Through a liberal-feminist lens, such appeals to motherhood can be interpreted as the (re)enactment of heteropartiarchal values, according to which a woman's role is to take care of her children. Following, then, all the commotion of the protests, these women will return to their houses and continue to play out their normative gender roles. In my opinion, such interpretations are limiting. Even if the female protests in Belarus function within a patriarchal framework, this does not mean that these frameworks cannot be subverted and renegotiated. For example, certain posters presenting reworked patriarchal stereotypes could be seen as subversive: "Sasha, I don't want you"24; "Now everybody understands everything. Even blond women showed up"; and "[This is a] march of women dissatisfied with the dictatorship." It follows that for many Belarusian women, the

20. Ibid., 739.

21. Dar'ia Chul'tsova, “'Ne mogla est' i pit' ot stressa.' Mat' piaterykh o zaderzhanii, shtrafe i reaktsii detei na eë vozvrashchenie," October 7, 2020, at https://lady.tut.by/news/ mylife/703056.html (accessed February 4, 2021).

22. Ibid.

23. To follow the arguments about the importance of emotions for social actions see Chris Shilling, "The Two Traditions in the Sociology of Emotions," The Sociological Review 50, no. 2 (2002): $10-32.32$

24. Sasha is a short form from the name Aliaksandar. This is a reference to Aliaksandar Lukashenka. 
subversion of patriarchally-prescribed gender roles is the only way to-at least symbolically-assert their power and dignity. These slogans thus appear as individual acts of maintaining agency, and, as such, become safe instruments for the expression of women's emotions.

Another form of women's protest is their situational reaction to police brutality. It is common for women to fight back; they try to break through police barricades, or attempt to prevent the detention of protestors who are dragged away by the riot police. They might even unmask men in combat gear. Most often, they simply embrace the officers and hand out flowers to them. Whereas the situations when women demonstrate power and fearlessness towards people in uniform are seen as an appropriate form of resistance, cases such as hugging and giving out flowers are perceived as a humble acceptance of the patriarchal authorities' methods of oppression.

Women who are involved in these acts, however, often do not agree with interpretations in which they are seen as uncritical objects of manipulation. The history of Ol'ga, a woman who was handing flowers to men in uniform, attests to this. Ol'ga's act took place at the moment of her arrest. In her tut. by interview, Ol'ga stated that she was not ashamed of what she had done. ${ }^{25}$ Being a psychologist, she explained that she tries to understand the motives of those who detained her. At the same time, she stated that she cannot accept their behavior, and the only instrument with which she could confront these armed men was her courage. This shows that even though these acts are just spontaneous reactions to situations in which many Belarusian women appear on the streets, it allows them to regain the agency that had been taken away from them. Moreover, just like her fellow female protesters, $\mathrm{Ol}^{\prime}$ ga appeals to women's pride and self-esteem, traits that allow them to claim a moral high ground over the regime. In her opinion, this moral high ground is also given to her through motherhood: "I'm a Belarusian woman. I'm a mother. I went to the march because I couldn't do otherwise. I have nothing to be ashamed of. I am proud of it." 26

In the Belarusian context, the discourse of female moral agency, which is actively used by female protesters and reproduces the culturally-strong conviction about the power of female self-sacrifice, functions as a reasonable discursive strategy. ${ }^{27}$ Belarusian women who take part in protests are convinced that their biological role-the ability to bear children and be a mother-positions them differently in society and enables them to protect a sphere that is reserved for them with all its implied resources. They are aware that this strategy is essential for the "common good," which goes beyond caring for their families and stretches to encompass society at large.

At the same time, caring for the common good as a legitimate area of activity for women can also be done by methods that subvert the normative status

25. Dar'ia Chul'tsova, “'Mne nechego stydit'sia'. Zhenshchina, darivshaia tsvety silovikam vo vremia zaderzhaniia, rasskazala o svoikh motivakh," September 29, 2020, at https://lady.tut.by/news/mylife/702230.html?utm_source=telegram\&utm_ campaign=share\&utm_medium $=$ social\&utm_content=desktop $\quad$ (accessed February 4, 2021).

26. Ibid.

27. Salmenniemi, “Civic Activity-Feminine Activity?” 745. 
quo. One of the ways to practice this is to playfully engage with entrenched stereotypical gender roles using ironic slogans. In that way, women engage in a form of a negotiation that makes the stereotypes work to their benefit. Protest slogans on women's posters play with normative femininity and masculinity through the reversal of stereotypical gender roles. Within the slogans, it is the women who feel the moral right to talk about dissatisfaction with the current political regime and Lukashenka himself. Women compare Lukashenka to the stereotypical, idle husband who fails to provide safety, welfare, and sexual satisfaction.

These strategies are fully accepted by Belarusian female protesters as they see themselves as the only social actors who possess the sufficient moral high ground for action. Post-Soviet researchers of gender tend to see the source of this female moral advantage in the heritage of the Soviet past of the east European region, where for decades women have played a leading role in taking care of the whole of society when, as it was during and after the wartime period, a lot of men were dead or injured. ${ }^{28}$ It was the women who then took over the reconstruction of the country, simultaneously maintaining the household and family. Such "total motherhood" may be considered a sphere of sacrum, or taboo that is unbreakable both by men and authorities. Meanwhile, this is a sphere in which women can exercise their freedom and agency. Thus, certain cultural patterns and specific underpinnings made visible under ethnographic scrutiny can shed light onto specific behaviors and strategies, allowing us to understand the "game" of subverting and negotiating women's roles in the fight against the regime. On the whole, this can open up a better understanding of the role of women and their "soft power" in resistance movements.

Furthermore, this shows that women can find their own niches of agency which they practice within oppositional movements that might at first glance be perceived as a masculine activity. Still, operating within available gendered patterns, women's agentic acts appear as, following Mahmood, one of many modalities of agency in which the fact of being subjected to established gendered norms does not eliminate the possibility of transgressing them. ${ }^{29} \mathrm{The}$ only further question in this context concerns the effects of this transgression: is there potential for a collective female formation that will support a women's agenda as the next step in their civic activism?

28. Salmenniemi, “Civic Activity-Feminine Activity?”; Oleg Riabov, Matushka-Rus': Opyt gendernogo analiza poickov natsional'noi identichnosti Rossii $v$ otechectvennoi $i$ zapadnoi istoriografii (Moskow, 2001).

29. Mahmood, Politics of Piety. 